\title{
EXPLORING THE RELATIONSHIPS BETWEEN EARLY CHILDHOOD IN-SERVICE TEACHERS' CLASSROOM MANAGEMENT AND SELF-REGULATION SKILLS
}

\author{
Begüm Canaslan Akyar', \\ Nuran Tuncer ${ }^{2 \mathrm{i}}$ \\ ${ }^{1}$ Lecturer, \\ Child Development, \\ Tarsus University, \\ Mersin, Turkey \\ orcid.org/0000-0002-9032-6631 \\ ${ }^{2}$ Associate Professor, \\ Faculty of Education, \\ Tokat Gaziosmanpasa University, \\ Tokat, Turkey \\ orcid.org/0000-0002-8748-5084
}

\begin{abstract}
:
Self-regulation skills allow individuals to control emotions, behaviors, and thoughts. Teachers' management of their behaviors, emotions, and thoughts could impact their classroom management too. Thus, teachers' self-regulation and classroom management relationships were analyzed in the study. To date, emotional regulation was studied, but self-regulation has not been studied in classroom management context. The study was designed as a quantitative study. Two hundred forty-four early childhood in-service teachers participated in the study. Correlation tests were used to analyze gathering data. The study result shows that self-regulation skills and classroom management are not correlated. On the other hand, there is a relationship between all three sub dimensions of self-regulation (self-monitoring, self-evaluation, self-reinforcement) and classroom management skills. The study result suggests that the early childhood teachers' selfreinforcement is positively correlated with classroom management skills. In addition, self-evaluation and self-monitoring are negatively correlated with classroom management. The study recommends that the teachers could increase their classroom management skills with internal or external rewards. Furthermore, the teachers can use some standard grade scales to observe whether they have misconceptions about classroom management strategies objectively.
\end{abstract}

Keywords: self-monitoring, self-reinforcement, self-evaluation, early childhood education

'Correspondence: email nurantuncer72@gmail.com 


\section{Literature Review}

\subsection{Classroom Management}

Classroom management is a critical issue in teaching because classroom management is the first step in teaching content (Cochran-Smith \& Villegas, 2016). Evertson and Weinstein (2006) describe classroom management as creating an environment for supporting and facilitating both academic and social-emotional learning taken by teachers. Classroom management combines some different elements such as time management, climate, learning activities, monitoring and maintaining behavior (Capizzi, 2009). Time management is concerned with allocated time, task on time, and academic learning time (Feldman, 2003). The climate covers the organizing space, time, and materials in the classroom (Rischer, 2008). The learning activities contain planning, examples, sequencing, practice, and assessment parts (Feldman, 2003). Monitoring and maintaining behavior are related to communication that is teachers can engage children to pay attention to activity with and without words (Glazer, 2003). Effective classroom management allows teachers to let the children as a part of class decisions. They are "within" what is happening in the classroom. These teachers can manage their classes in a professional, business-like manner (Cangelosi, 2014). Additionally, classroom management is defined as strategies that provide physiological and psychological security, regulate children's behavior, self-discipline, and contribute to the flow of events during the classroom (Manning \& Bucher, 2013). In other words, organizing the classroom environment and managing children's behaviors are vital to reaching desired learning outcomes for a teacher via classroom management (Lester et al., 2017).

Classroom management is generally related to teachers' strategies, however teachers' self-management is rarely taken into account. (Martin et al., 2016). Literature shows that personality traits, professional and organizational issues have a medium-size effect on teachers' classroom management skills (Kaya \& Selvitopu, 2019). Several studies, such as De Jong et al. (2014) and Đigić, (2018), have been carried out on pre and in-service teachers' characteristics and student-teacher relationships in classroom management. Both study results show that pre and in-service teachers' characteristics impact classroom management. Sutton (2009) also found that emotional regulations impact teacher-child relationships, discipline and emotional regulated teachers are more effective in classroom management. Regulating their emotions and reducing negative emotions make teachers more confident in communication. As Blömeke and Delany (2012) suggested, a teacher can clearly define her professional objectives, choose appropriate strategies to reach her aims, and apply the strategies in various conditions when regulating her behavior. 


\subsection{Teachers' Self-Regulation}

To date, self-regulation is defined in different aspects. For instance, self-regulation is defined as developing, implementing, and maintaining a flexible planned behavior to reach an individual's own goals (Brown et al., 1999; Hadwin \& Oshige, 2011). Zimmerman defined self-regulation in education fields as self-generated and systematically designed thoughts, behaviors, and feelings to learning knowledge and skills (2000). Kanfer also proposed a self-regulatory model. In the model, self-regulation is activated when a person's behavior is disturbed (1970). Such circumstances like skill acquisition, conflict, disruption because of environmental or biological variables, or obscurity of the behavioral chain cause self-regulation. There are three phases of selfregulation in the Kanfer's (1970) model. (a) self-evaluation, (b) self-monitoring are to compare a person's performance to a standard, and (c) self-reinforcement is verbal or symbolic consequences of a person's performance based on the self-evaluation. In other words, Kanfer's model focuses on the behavioral aspect of self-regulation. Our study's theoretical background stands on Kanfer's self-regulation model.

Controlling behavior, emotions, and thought has a crucial role in good relationships and success in daily life (Zimmerman, 2000). Moreover, self-regulation is a combination of some abilities that protect individuals from overreaction to provocation and being left at compassion from environment (Vink et al., 2020). According to most theories, self-regulation plays an essential role in controlling behavior, facilitating positive behavior, and decreasing undesired behaviors (Vink et al., 2020). Self-regulated learners can set their goals, manage their time, arrange environment structure and have task strategies (Barnard-Brak et al., 2010). Since self-regulated individuals know how to interpret their strengths and weaknesses, evaluate their work status, focus on a target and spending energy, and take advantage of opportunities and resources, they can achieve their goals (Gestsdottir et al., 2010).

Self-regulation guides teachers in their own professional life (Capa-Aydin et al., 2009). Teacher self-regulation is defined as strategies that teachers apply to cope with professional barriers like high workload or reach their professional aims in the workplace (Mattern \& Bauer, 2014). The teachers' self-regulation has been searched, and a study result shows that teachers' self-regulation most probably has a fundamental role in-class instruction (Capa-Aydin et al., 2009). For instance, teachers consult self-regulation in front of disruptive children or building effective classroom management (Mattern \& Bauer, 2014). Capa-Aydin et al. suggested that these characteristics are beneficial to improve instruction quality. Self-regulated teachers use various teaching strategies throughout instruction and change the strategies if required (Capa-Aydin et al., 2009). Moreover, different kinds of self-regulation strategies are required in the different relationships of teachers' professions, like changing classroom atmosphere, afflicting parents or colleagues (Endedijk et al., 2012).

Teachers have a better vision for better possible learning opportunities for both students and themselves since self-regulated teachers may become aware of their sense of both specific learning and teaching strategies linked with knowledge development 
(Paris \& Winograd, 2003). Teachers' self-regulation helps them to set goals, control and evaluate their cognition, behavior, and motivation (Zimmerman, 2008). A study suggested that emotional regulation is an influential factor in classroom management, discipline, and relationships with students (Sutton et al., 2009). Moreover, another study shows that teachers' self-regulation allows teachers to use various teaching strategies, change these strategies when needed, keep calm in front of problems. All these characteristics are suspected of developing the quality of instruction (Capa-Aydin et al., 2009). Therefore, teachers' self-regulation could be related to effective classroom management. However, there are limited studies about in-service early childhood teachers' self-regulation studies in the Turkish context. Studies generally refer to preschool children or pre-service teachers' self-regulation. For this reason, in-service early childhood teachers' self-regulation research needs to be examined. Additionally, very little is known about early childhood teachers' self-regulation and classroom management relationships in the literature. To fill the gap in the literature, the current study seeks to answer the following questions;

- Is there any relationship between early childhood teachers' self-regulation and classroom management skills?

a. Is there any relationship between communication and behavioral regulations and self-regulation skills?

b. Is there any relationship between classroom physical arrangements and self-regulation skills?

c. Is there any relationship between time management and self-regulation skills?

d. Is there any relationship between plan-program activities and selfregulation skills?

e. Is there any relationship between self-reinforcement and classroom management skills?

f. Is there any relationship between self-monitoring and classroom management skills?

g. Is there any relationship between self-evaluation and classroom management skills?

\section{Material and Methods}

The study aims to explore the relationships between early childhood in-service teachers' classroom management and self-regulation skills. The study is quantitative and was employed as a correlational study because the correlational research method investigates relationships between just two variables without manipulating variables (Fraenkel, et al., 2012). The researcher explored two continuous variables: classroom management and self-regulation skills of early childhood in-service teachers regarding their relationship. The other details about the participants, data collection procedure, and the measurement process are presented. 


\subsection{Participants}

Table 1: Demographic Descriptive Statistics

\begin{tabular}{|l|c|c|}
\hline Characteristics & Number & Percentage \\
\hline Gender & 244 & 96.8 \\
\hline Female & 8 & 3.2 \\
\hline Male & 156 & 64.4 \\
\hline Graduated Program & 38 & 15.8 \\
\hline Undergraduate & 25 & 10.5 \\
\hline Open University & 15 & 6.9 \\
\hline Associate Program & 3 & 1.6 \\
\hline Graduate Program & 7 & 0.8 \\
\hline Associate Open University & \multicolumn{2}{l|}{} \\
\hline Vocational High School & 117 & 47.4 \\
\hline Working School & 68 & 27.5 \\
\hline Public Kindergarten & 27 & 11.3 \\
\hline Public Preschool & 17 & 7.3 \\
\hline Private Preschool & 9 & 3.7 \\
\hline Kindergarten within Institution & 6 & 2.8 \\
\hline Others & & \\
\hline Vocational High School & & \\
\hline
\end{tabular}

Participants of the study were 244 early childhood teachers in Turkey. The teachers were chosen by convenience sampling method. The average age of teachers was 33.56, and the teachers have 9.79 average years of teaching experience. $96.8 \%$ of the participants are female, 3.2\% male. The participant teachers have graduated schools with $64.4 \%$ undergraduate, $15.8 \%$ open university, $10.5 \%$ associate program, $6.9 \%$ graduated program, a $1.6 \%$ open university associate program, and a $0.8 \%$ vocational high school. The teachers are working in public kindergarten (47.4\%), public preschool (27.5\%), private preschool $(11.3 \%)$, kindergarten within the institution $(7.3 \%)$, vocational high school's practice kindergarten $(2.8 \%)$, and others (3.7\%) respectively (see Table 1$)$.

\subsection{Instrument}

Data of the study was gathered by using the teacher questionnaires. Teachers' questionnaire was either delivered by hand or sent online via by Google forms. The teacher questionnaire contains three sections. Demographic information was asked like teachers' age, type of graduated school, and years of teaching experience. In the second part, the teachers' classroom management skills were measured through Early Childhood Educator's Classroom Management Skills Scale (Kaplan \& İlgar, 2018). Finally, the teachers' self-regulation skills were asked by Turkish Version of SelfRegulation Questionnaire (Solmaz, Keskin, \& Yel, 2012). The overall data gathered process took nine months. 


\subsubsection{Early Childhood Educator's Classroom Management Skill Scale}

Kaplan and İlgar developed the scale in 2018. This scale includes 49 items and four subdimensions. These are (a) communication and behavioral regulations, (b) classroom physical arrangements, (c) time management, and (d) plan-program activities. The scale is 5 Likert types, ( $5=$ Excellent, $4=$ Good, $3=$ Fair, $2=$ Poor, $1=$ Very Poor). The highest score on the scale is 245 , and the lowest score is 49 . The scores between 49 and 114 average, 181 , and 245 are showing a high level of classroom management skills. The Cronbach alpha value results of the scale were presented as $\alpha=.974$ for overall scale, communication and behavior regulation sub dimensions is calculated as $\alpha=.961$, physical arrangements are $\alpha=.882$, plan-program activities are $\alpha=.914$, and time management is $\alpha=.974$. For the current study, the Cronbach alpha value results of the scale was presented as $\alpha=.963$. For the overall scale, physical arrangements sub dimensions was $\alpha=.853$, plan-program activities subscale was $\alpha=.882$, communication and behavior regulation subscale was calculated as $\alpha=.949$, and time managements subscale was $\alpha=.790$.

\subsubsection{Self-Regulation Questionnaire}

The questionnaire was developed by Brown, Miller, and Lawendowski (1999) to measure behavior self-regulation. This scale is a Likert scale having 5 points ( $1=$ strongly disagree, and $5=$ strongly agree). The scale was adapted in Turkish by Aydın, Özer-Keskin, and Yel (2012). The original scale contains 63 items and seven sub dimensions. However, the Turkish version of the questionnaire includes 51 items and has three factors. Based on the scale, 159 and lower score is categorized as low self-regulation, between 160 and 197 medium self-regulation, 198 and higher scores are high self-regulation skills. The three factors are created based on Brown, Miller's (1991) self-regulation model, selfmonitoring, self-evaluation, and self-reinforcement. Reliability was determined through calculated Cronbach $\alpha$ factor, the total questionnaire $\alpha=.87$; self-reinforcement $\alpha=.88$; self-monitoring $\alpha=.87$ and self-evaluation $\alpha=.60$ were found in the Turkish version (Aydın, Özer-Keskin \& Yel, 2012). For the current study, the total questionnaire was calculated $\alpha=.765$; self-reinforcement $\alpha=.869$; self-monitoring $\alpha=.892$ and self-evaluation $\alpha=.559$.

\subsection{Data Analysis}

The data was analyzed through the statistical analysis program SPSS V.22. Descriptive statistics were run for Early Childhood Educator's Classroom Management Skill Scale to check normality, missing data, and detecting outliers. After that, a self-regulation questionnaire was analyzed in terms of normality, missing data, and outliers. Three data were excluded because of outliers. Two hundred forty-four participants remained after descriptive statistical analysis. The analysis result shows that normality is violated for the data set. Exploratory analyses were used to determine the associations between teachers' self-regulation and classroom management skills. The associations were analyzed by Spearman rank correlation, which is a non-parametric test of bivariate correlation. 


\section{Results and Discussion}

In this section, the early childhood teachers' classroom management skills score, selfregulation score, and correlation results between classroom management skills and selfregulation are shown.

\subsection{Early Childhood Educator's Self-Regulation Skills}

The descriptive statistics of the Self-Regulation Questionnaire is presented. The result shows that the teachers' overall self-regulation $\mathrm{M}=162.92 ; \mathrm{SD}=13.9$; self-monitoring $\mathrm{M}=$ 36. 87 ; $\mathrm{SD}=11.8$; self-reinforcement $\mathrm{M}=116.3$; $\mathrm{SD}=12.3$; self-evaluation $\mathrm{M}=9.7 ; \mathrm{SD}=3.0$ (see Table 2).

Table 2: Self-Regulation Questionnaire Score ( $\mathrm{N}=244)$

\begin{tabular}{|l|c|c|}
\hline Scale & M & SD \\
\hline Self-regulation Questionnaire & 162.92 & 13.9 \\
\hline Self-monitoring & 36.87 & 11.8 \\
\hline Self-reinforcement & 116.3 & 12,3 \\
\hline Self-evaluation & 9.7 & 3.0 \\
\hline
\end{tabular}

\subsection{Early Childhood Educator's Classroom Management Skills}

The descriptive statistics of Early Childhood Educator's Classroom Management Scale result is represented. The analysis result shows that $M=219.11 ; S D=19.41$. The sub dimensions' results are like that classroom physical arrangement $\mathrm{M}=43.35 ; \mathrm{SD}=4.97$; plan-program activity $\mathrm{M}=39.54 ; \mathrm{SD}=4.34$; communication and behavioral regulation $\mathrm{M}=$ 109.07; $\mathrm{SD}=10.03$; and time management $\mathrm{M}=27.7 ; \mathrm{SD}=3.29$ (see Table 3).

Table 3: Early Childhood Educator's Classroom Management Skills Scores (N=244)

\begin{tabular}{|l|c|c|}
\hline Scale & M & SD \\
\hline Overall C.M.S & 219.11 & 19.41 \\
\hline Classroom physical arrangements & 43.35 & 4.97 \\
\hline Plan-program activities & 39.54 & 4.34 \\
\hline Communication and behavioral regulations & 109.07 & 10.03 \\
\hline Time management & 27.7 & 3.29 \\
\hline
\end{tabular}

\subsection{Correlations Between Classroom Management Skills and Self-Regulation}

Table 4 illustrates the bivariate correlations between self-regulation and overall classroom management skills. Hence, normality assumption was violated, the Spearman Rho test was conducted. Overall classroom management and self-regulation skills were not statistically significant at .05 level $(\mathrm{r}=.054, \mathrm{p}=.40)$, meaning the two sets of variables are not correlated. 
Table 4: Spearman-Rho Result of Self-regulation and Classroom Management

\begin{tabular}{|l|l|c|c|}
\hline \multicolumn{2}{|c|}{} & Self-regulation & Classroom Management \\
\hline \multirow{3}{*}{ Self-regulation } & Pearson Correlation & 1.000 & .054 \\
\cline { 2 - 4 } & Sig. (2-tailed) &. & .402 \\
\cline { 2 - 4 } & $\mathrm{N}$ & 244 & 244 \\
\hline \multirow{3}{*}{ Classroom Management } & Pearson Correlation & .054 & 1.000 \\
\cline { 2 - 4 } & Sig. (2-tailed) & .402 &. \\
\cline { 2 - 4 } & $\mathrm{N}$ & 244 & 244 \\
\hline
\end{tabular}

\subsection{Correlation Between Self-regulation and Classroom Management's Subdimension Skills}

The sub dimensions of classroom management skills are classroom physical arrangement, plan-program activities, time management, communication and behavioral regulations. These sub dimensions of classroom management skills were correlated with self-regulation questionnaire. The normality assumption was violated for the data set; therefore, Spearman Rho test was run for each analysis. According to the results of the Spearman Rho, there was not a significant correlation between self-regulation and classroom physical arrangement skills at .05 level $(\mathrm{r}=.019, \mathrm{p}=.77)$; plan-program activities at .05 level $(\mathrm{r}=.093, \mathrm{p}=.15)$; time management at .05 level $(\mathrm{r}=.014, \mathrm{p}=.83)$; and communication and behavior regulations at .05 level $(\mathrm{r}=.052, \mathrm{p}=.42)$ (see Table 5).

Table 5: Spearman Rho Results of Self-regulation and Classroom Physical Arrangement

\begin{tabular}{|l|l|c|}
\hline \multicolumn{2}{|l|}{} & Self-regulation \\
\hline \multirow{4}{*}{ Classroom physical arrangement } & Correlation Coefficient & .019 \\
\cline { 2 - 3 } & Sig. (2-tailed) & .772 \\
\cline { 2 - 3 } & $\mathrm{N}$ & 244 \\
\hline \multirow{3}{*}{ Plan-program activities } & Correlation Coefficient & .093 \\
\cline { 2 - 3 } & Sig. (2-tailed) & .148 \\
\cline { 2 - 3 } & $\mathrm{N}$ & 244 \\
\hline \multirow{4}{*}{ Time management } & Correlation Coefficient & .014 \\
\cline { 2 - 3 } & Sig. (2-tailed) & .826 \\
\cline { 2 - 3 } & $\mathrm{N}$ & 244 \\
\hline \multirow{4}{*}{ Communication and behavior regulations } & Correlation Coefficient & .052 \\
\cline { 2 - 3 } & Sig. (2-tailed) & .417 \\
\cline { 2 - 3 } & $\mathrm{N}$ & 244 \\
\hline
\end{tabular}

\subsection{Correlation Between Classroom Management Skills and Self-Regulation Sub dimensions}

The three sub dimensions of self-regulation scale are self-reinforcement, self-monitoring, and self-evaluation. The correlation between classroom management and the three sub dimensions were analyzed by Spearman Rho test.

The Spearman Rho test analysis shows that there is a positive significant correlation between classroom management and self-reinforcement at .05 level $(\mathrm{r}=.439$, $\mathrm{p}=.00)$ with a medium effect size $(\mathrm{r} 2=.192)$. 
Nevertheless, the correlation between classroom management and selfmonitoring, the Spearman Rho test shows that there is a negative significant correlation between classroom management and self-monitoring at .05 level ( $r=.-401, p=.00)$ with a medium effect size $(\mathrm{r} 2=.161)$.

According to Spearman Rho analysis, there is a negative correlation between classroom management and self-evaluation at .05 level $(r=-.143, p=.025)$ with a small effect size $(\mathrm{r} 2=.02)$ (See Table 6).

Table 6: Spearman-Rho results of classroom management and self-reinforcement

\begin{tabular}{|l|l|c|}
\hline \multicolumn{2}{|l|}{} & Classroom Management \\
\hline \multirow{3}{*}{ Self-reinforcement } & Correlation Coefficient & .439 \\
\cline { 2 - 3 } & Sig. (2-tailed) & .000 \\
\cline { 2 - 3 } & $\mathrm{N}$ & 244 \\
\hline \multirow{3}{*}{ Self-monitoring } & Correlation Coefficient & -.40 \\
\cline { 2 - 3 } & Sig. (2-tailed) & .000 \\
\cline { 2 - 3 } & $\mathrm{N}$ & 244 \\
\hline \multirow{3}{*}{ Self-evaluation } & Correlation Coefficient & -.143 \\
\cline { 2 - 3 } & Sig. (2-tailed) & .025 \\
\cline { 2 - 3 } & $\mathrm{N}$ & 244 \\
\hline
\end{tabular}

\section{Discussion}

The study aims to analyze the relationship between early childhood teachers' classroom management and self-regulation skills. These results also answer the relationship between classroom management sub dimensions and self-regulation sub dimensions skills of early childhood teachers. Previous studies revealed that teachers' emotional regulation skills impact their classroom management strategies (Sutton et al., 2009) and apply self-regulation strategies when they can regulate their behaviors (Blömeke \& Delany, 2012). The results of the study show that early childhood teachers have a medium level of self-regulation skills. Additionally, early childhood teachers have high classroom management skills. The data analysis showed no correlation between early childhood educator's self-regulation and classroom management skills. However, the current research shows a significant relationship between three sub dimensions of selfregulation; self-monitoring, self-reinforcement, self-evaluation, and classroom management skills. There is a positive correlation between self-reinforcement and classroom management skills.

The early childhood teachers' self-regulation skills were found to be of medium level. Parallel with our result, Yilmaz (2016) and Kurt (2020) found a medium selfregulation level of early childhood teachers. Early childhood teachers' self-regulation skills are important because they would be role models for their students' self-regulation development (Dignath \& Büttner, 2018). The teachers' self-regulation skills also impact building positive relationships with the teacher-child dyad and increasing effective classroom management practices in the education environment (Iriogbe-Efionayi, 2020). 
Classroom management skills of the early childhood teachers are found at a high level in our study. Similarly, with our results, some studies show that early childhood teachers' classroom skills are high level (Adıgüzel \& İpek, 2016; Sadık \& Dikici-Sığırtmaç, 2016; Zembat \& Küsmüş, 2020) found that high classroom management score of early childhood teachers. On the other hand, some studies conducted as observation show that early childhood teachers do not exhibit appropriate classroom management skills (Akgün et al., 2011). For this reason, the current study tries to explain early childhood teachers' classroom management and self-regulation relationship. Surprisingly, there is no relationship between early childhood teachers' overall classroom management and self-regulation skills. However, there is a relationship between self-regulation sub dimensions and classroom management.

The study result shows that there is a positive correlation between selfreinforcement and classroom management skills. Verbal expressions or external rewards are used as a motivation tool in self-reinforcement (Kanfer, 1970). As DeLamarter and Krepps (1980) suggest, our study proposing that early childhood teachers perceived an external factor as a motivational tool for effective classroom management. Cihak and Gama (2008) also argued that self-reinforcement is related to maintain on-task behavior and self-management. The current study result argues that the early childhood teachers' self-reinforcement can support and maintain their classroom management skills. When they would have external rewards and verbal expressions, they would have high classroom management skills. To sum up, teachers can exhibit effective classroom management skills to take verbal expression, reward, or escape from punishment.

According to the study's other findings, the early childhood teachers' selfmonitoring and classroom management are negatively correlated. This finding was unexpected because self-monitoring supports self-awareness of teachers' behavior and changing their behaviors (Rispoli et al., 2017). Aybek and Aslan (2017) suggested that high self-monitoring skills are expected skills for an effective teacher. However, our study result shows that our early childhood teachers have a low level of self-monitoring skills. Although self-monitoring is a required skill for teachers, Kanfer (1970) stated that teachers do not adequately observe and evaluate themselves. Thus, our study results can be explained that teachers' self-monitoring skills negatively affect their classroom management skills because they can lose their objectivity while they monitor themselves. Similarly, Oliver et al. (2015) study revealed that when teachers use a checklist to be objective while self-monitoring, they can successfully implement a new classroom management strategy. Hence, the teachers could tend to be subjective while observing their actions in the classroom, high levels of self-monitoring cause to decrease classroom management skills. Teachers could maintain behaviors or strategies in classroom management even if they are not appropriate. In order to prevent this, behaviors are consciously observed, results are recorded, and gathered data is used to make informed decisions (Bruhn et al., 2015). The teachers can use different strategies to self-monitor, and they can record their analysis, then use the analysis to improve classroom 
management skills. Therefore, they may need some tools to provide objectivity, like a checklist.

Another unexpected finding is that there is a negative correlation between selfevaluation and classroom management skills. Since self-evaluation allows teachers to learn about their professional process (Carless et al., 2006), the current study result is expected to correlate between classroom management and self-evaluation positively. However, Kanfer and Karoly (1972) stated that self-evaluation skills work best when the active goal is used as an evaluation standard. Additionally, self-evaluation is not an objective process (Güngören et al., 2020), using grading scales like rubric, checklist, or open-ended questions are suggested to prevent subjectivity (Kutlu et al., 2008). Therefore, the study result could be explained that the teachers could not have an evaluation standard with themselves. Similar to the previous result, when teachers have standard evaluation items in self-monitoring, they can objectively evaluate their skills. Accordingly, teachers' self-evaluation was supported by giving effective feedback (Hattie \& Timperley, 2007). When the teachers have self-evaluation skills, the discrepancy between actual performance and self-evaluation could be reduced (Hattie \& Timperley, 2007). Remarkably, an item-based feedback system is suggested for improving selfevaluation (Callender et al., 2015). Our findings would seem to suggest that the teachers could need to evaluate themselves objectively. Thus, they need some graded scale or feedback. When the discrepancy between real and evaluation is increased, the teachers could be unsuccessful in the classroom management process.

\section{Conclusion and Implications}

Our work has led us to conclude that teachers' point of view makes learning easier. Thus, the classroom environment created by teachers has an essential role in making learning easier. Teachers' classroom management skills would be practical when they control their emotions, behavior, and thoughts. Early childhood is a critical period for learning rules and gaining behavior that quickly adopts children to later school and adult life.

The present research aimed to show the relationship between early childhood teachers' self-regulation skills and classroom management skills. This study has investigated that there is not a correlation between self-regulation and classroom management skills. However, the sub dimensions of self-regulation are correlated with classroom management whereas, classroom management sub dimensions have not. The evidence from this study suggests self-regulation and classroom management relationships are worthy of investigating.

The findings from this study make several contributions to the current literature. Firstly, early childhood teachers' self-reinforcement could positively impact classroom management skills. This means that external rewards or verbal expressions about teachers' classroom management could increase the teachers' effective classroom management skills. School administrations could increase those kinds of reinforcement, which results in internal motivation. We have outlined that self-monitoring negatively 
impacts classroom management. A satisfactory explanation for this is that the teachers subjectively monitor their performance. A second person could monitor, or camera recordings could be used to monitor the teachers' classroom management objectively. Then, the teachers could discuss or re-evaluate their classroom management skills. Similarly, self-evaluation negatively impacts classroom management. This may have occurred because the teachers lack objectivity, and they overstate their classroom management skills. The study could suggest that early childhood teachers can prepare a graded scale to evaluate themselves. In this way, they can objectively evaluate their classroom management skills.

\section{Limitations and Future Studies}

Our work clearly has some limitations. Despite this, we believe our work could be a starting point for investigating self-regulation and classroom management studies. The most important limitation lies in the fact that we used self-reflection instruments. This may prevent reflecting on the real situation of the teachers' classroom management skills. Therefore, future studies can be designed as a qualitative study via observation and interview to examine how early childhood teachers' self-regulation skills impact classroom management skills. Although there could not be a correlation in the current study, future studies could conduct the same study via various instruments with larger samples than the current study.

\section{Conflict of Interest Statement}

The authors declare no conflicts of interests.

\section{About the Authors}

Begum Canaslan-Akyar, my position is Lecturer of Child Development at Tarsus University where I conduct courses on Play, Drama, Educational Technology, Creativity and Visual Arts, Music, and Mathematics in Childhood at the associate degree level. Additionally, I am the Erasmus Coordinator of the Health Services Vocational School. My current research agenda is focused on playfulness, play, and digital technology use in the early childhood period.

Nuran Tuncer, Associate Professor at Department of Elementary Education at Tokat Gaziosmanpasa University, she got her doctoral degree from Gazi University, Institute of Educational Sciences in 2018. Her doctoral dissertation titled "An analysis of the effectiveness of the teacher training program regarding supporting preschool children' executive functions". Her research areas are Early Childhood Education, Pre-School Education, Executive functions, Early learning skills, Classroom strategies, Disadvantaged children, Preschool teachers, Teacher candidates, Parent education, Children' literature. 


\section{References}

Adıgüzel, İ, İpek, C, 2016. Okul Öncesi Öğretmenlerinin Sınıf Yönetimi Becerileri Ve Tükenmişlik Düzeyleri [The Relations Between Pre-School Teachers Classroom Management Skills And Burnout Level]. International Journal of Eurasia Social Sciences, 7:23, 247-273.

Akgün, E, Yılmaz, E, O, Seferoğlu, S, S, 2011. Vizyon 2023 Strateji Belgesi Ve Fırsatları Artırma Ve Teknolojiyi İyileştirme Hareketi (FATİH) Projesi: Karşılaştırmalı Bir Inceleme [Vision 2023 Strategy Document And Increasing Opportunities And Improvement Of Technology Project: A Comparative Analysis]. Akademik Bilişim, 2:4, 115-122.

Aybek, B, Aslan, S, 2017. An Analysis of the Self-Regulation Levels of Prospective Teachers in Terms of Certain Variables. Journal of Theory \& Practice in Education (JTPE), 13:3, 455-470.

Barnard-Brak, L, Lan, W, Y, Paton, V, O, 2010. Profiles in Self-Regulated Learning in the Online Learning Environment. The International Review of Research in Open and Distributed Learning, 11:1, 61-80. doi: 10.19173/irrodl.v11i1.769.

Blömeke, S, Delaney, S, 2012. Assessment of Teacher Knowledge Across Countries: A Review of the State of Research. ZDM. The International Journal on Mathematics Education, 44:3, 223-247. doi:10.1007/s11858-012-0429-7

Brown, J. M, Miller, W, R, \& Lawendowski, L, A, 1999. The Self-Regulation Questionnaire. In L. Vande Creek and T, L, Jackson (Eds.), Innovations in clinical practice: a source book (pp. 281-289). Sarasota, FL: Professional Resource Press.

Bruhn, A, McDaniel, S, Kreigh, C, 2015. Self-monitoring Interventions for Students with Behavior Problems: A Systematic Review of Current Research. Behavioral Disorders, 40:2, 102-121. doi:10.17988/BD-13-45.1

Callender, A, A, Franco-Watkins, A, M, \& Roberts, A, S, 2015. Improving Metacognition in the Classroom Through Instruction, Training, and Feedback. Metacognition and Learning, 11:2, 215-235. doi:10.1007/s11409-015-9142-6

Cangelosi, J, S, 2014. Classroom management strategies: Gaining and maintaining students' cooperation. 5th edn. Hoboken, NJ John, Wiley \& Sons.

Capa-Aydin Y, Sungur S, \& Uzuntiryaki E, 2009. Teacher Self-regulation: Examining a Multidimensional Construct, Educ. Psychol., 29:3, 345-356. doi:10.1080/01443410902927825.

Carless, D, Joughin, G, Mok, M, 2006. Learning-oriented Assessment: Principles and Practice. Assessment and evaluation in Higher Education, 31:4, 395-398. doi:10.1080/02602930600679043

Cihak, D, F, Gama, R, I, 2008. Noncontingent Escape Access to Self-Reinforcement to Increase Task Engagement for Students with Moderate to Severe Disabilities. Education and Training in Developmental Disabilities, 556-568.

Cochran-Smith, M., \& Villegas, A, M, 2016. Research on Teacher Preparation: Charting the Landscape of a Sprawling Field. In D. H. Gitomer \& C. A. Bell (Eds.), Handbook 
of research on teaching (pp. 439-547). Washington, DC, American Educational Research Association.

De Jong, R, Mainhard, T, Van Tartwijk, J, Veldman, I, Verloop, N, Wubbels, T, 2014. How Pre-Service Teachers' Personality Traits, Self-Efficacy, and Discipline Strategies Contribute to the Teacher-Student Relationship. British Journal of Educational Psychology, 84:2, 294-310. doi:10.1111/bjep.12025

Đigić, G, 2018. The Relationship Between Personal and Professional Characteristics of Teachers. Facta Universitatis-Philosophy, Sociology, Psychology and History, 17(01), 1-18.

Dignath, C, Büttner, G, 2018. Teachers' Direct and Indirect Promotion of Self-Regulated Learning in Primary and Secondary School Mathematics Classes-insights from Video-Based Classroom observations and Teacher Interviews. Metacognition Learning, 13:2018, 127- 157. doi:10.1007/s11409-018-9181-x

Endedijk, M, D, Vermunt, J, D, Verloop, N, Brekelmans, M, 2012. The Nature of Student Teachers' Regulation of Learning in Teacher Education. British Journal of Educational Psychology, 82: 469-491. doi:10.1111/j.2044-8279.2011.02040.x

Evertson, C, M, Weinstein, C, S, 2006. Classroom Management as a Field of Inquiry. In C. M. Evertson \& C. S. Weinstein (Eds.), Handbook of classroom management: Research practice and contemporary issues (pp. 3-16). Mahwah, NJ, Lawrence Erlbaum Associates.

Feldman, S, 2003. Are You Using Your Time Wisely? Teaching Pre K-8, 35:8, 6.

Fraenkel, J, R, Wallen, N, E, Hyun, H, H, 2012. How to design and evaluate research in education, 8th edn. New York, McGraw-Hill.

Gestsdottir, S, Bowers, E, von Eye, A, Napolitano, C, M, Lerner, R. M. 2010. Intentional Self-Regulation in Middle Adolescence: The Emerging Role of Loss-Based Selection in Positive Youth Development. Journal of Youth and Adolescence, 39:7, 764-782.

Glazer, S, M, 2003. Quiet Signals. Teaching Pre K-8, 34:2, 86-87.

Güngören, S, Ç, Hasançebi, F, Y, Mesci, G, 2020. The Effect of Teacher Evaluation and Self- Evaluation on Pre-Service Teachers' Inquiry-Based 5E Lesson Plan Design and TeachingPractice. Educational Policy Analysis and Strategic Research, 15:4, 367-388. doi:10.29329/epasr.2020.323.20

Hadwin, A, Oshige, M, 2011. Socially Shared Regulation: Exploring Perspectives of Social in Self-Regulated Learning Theory. Teachers College Record, 113:2, 240-264.

Hattie, J, Timperley, H, 2007. The Power of Feedback. Review of Educational Research, 77:1, 81-112. doi:10.3102/003465430 298487

Iriogbe-Efionayi, S, 2020. Promoting self-regulation in Early Childhood Education: Teachers' Knowledge of Self-Regulation. Urban Education Research \& Policy Annuals, 7:1.

Kanfer, F, H, 1970. Self-regulation: Research, Issues, and Speculation, In C. Neuringer \& J.L. Michael (Eds.), Behavior modification in clinical psychology (pp. 178-220). New York, Appleton-Century-Crofts. 
Kanfer, F, H, Karoly, P, 1972. Self-control: A Behavioristic Excursion into The Lion's. Behavior Therapy, 3:3, 398-416.

Kaya, M, Selvitopu, A, 2019. A Meta-Analysis of the Effects of Some Factors on Teachers' Classroom Management Skills. International Journal of Contemporary Educational Research, 6:2, 409-425. doi:10.33200/ijcer.621313.

Kutlu, Ö, Doğan, C, D, Karakaya, İ, 2009. Öğrenci başarısının belirlenmesi performansa ve portfolyoya dayalı durum belirleme [Determination of student success determination based on performance and portfolio] (2. Bask1). Pegem Akademi.

Lester, R, R, Allanson, P, B, Notar, C, E, 2017. Routines Are the Foundation of Classroom Management. Education, 137:4, 398-412.

Manning, M. L., Bucher, K. T. (2013). Classroom management: models, applications, and cases, 3rd edn, Pearson \& Merrill Prentice Hall, Upper Saddle River, NJ.

Martin, N, K, Schafer, N, J, McClowry, S, Emmer, E, T, Brekelmans, M, Mainhard, T, Wubbels, T, 2016. Expanding The Definition of Classroom Management: Recurring Themes and New Conceptualizations. Journal of Classroom Interaction, 51:1, 31-41.

Mattern, J, Bauer, J, 2014. Does Teachers' Cognitive Self-Regulation Increase Their Occupational Well-Being? The Structure and Role of Self-Regulation in the Teaching Context. Teaching and Teacher Education, 43, 58-68. doi:10.1016/j.tate.2014.05.004

Oliver, R, M, Wehby, J, H, Nelson, J, R, 2015. Helping Teachers Maintain Classroom Management Practices Using a Self-Monitoring Checklist. Teaching and Teacher Education, 51, 113-120. doi:10.1016/j.tate.2015.06.007

Paris, S, G, Winograd, P, 2003. The Role of Self-Regulated Learning in Contextual Teaching: Principles for Teacher Preparation. Retrieved from ERIC database (ED479905).

Rischer, A. D. (2008). Management Strategics Help to Promote Student Achievement. Education Digest, 74:3, 47-49.

Rispoli, M, Saini, S, Mason, R, Brodhead, M, Burke, M, D, Gregori, E, 2017. A Systematic Review of Teacher Self-Monitoring on Implementation of Behavioral Practices. Teaching and Teacher Education, 63, 58-72. doi:10.1016/jtate.2016.12.007.

Sadık, F, Dikici Sığırtmaç, A, 2016. Okul Öncesi Öğretmenlerinin Sınıf Yönetim Becerileri ve Uygulamalarına Yönelik Görüşlerinin İncelenmesi [Investigating The Views of Pre- SchoolTeachers about Classroom Management Skills and Practices]. International Periodical for the Languages, Literature and History of Turkish or Turkic 11:14, 631- 664. doi:10.7827/TurkishStudies.9630

Sutton, R, E, Mudrey-Camino, R, \& Knight, C, C, 2009. Teachers' Emotion Regulation and Classroom Management. Theory into Practice, 48:2, 130-137. doi:10.1080/00405840902776418

Vink, M, Gladwin, T, E, Geeraerts, S, Pas, P, Bos, D, Hofstee, M., ... Vollebergh, W. 2020. Towards an Integrated Account of the Development of Self-Regulation From a Neurocognitive Perspective: A Framework for Current and Future Longitudinal 
Multi-Modal Investigations. Developmental Cognitive Neuroscience, 45:2020, 100829. doi:10.1016/j.den.2020.100829

Yılmaz, H, 2016. Okul öncesi öğretmenlerinin öz-düzenleme düzeyleri ile kullandıkları öğretim uygulamaları düzeyleri arasındaki ilişkinin incelenmesi [Analyzing the relationship between preschool teachers' levels of self-regulation and levels of teaching practices they use]. Master Thesis, Marmara University

Zembat, R, Küsmüş, G, İ, 2020. Okul Öncesi Öğretmenlerinin Sınıf Yönetimi Becerileri İle Mesleki Profesyonellikleri Arasındaki İlişkinin İncelenmesi [Analyzing The Relationship Between Preschool Teachers' Classroom Management Skills and Occupational Professionalism]. Kastamonu Eğitim Dergisi, 28:4, 1725-1739.

Zimmerman, B, J, 2000. Attaining Self-regulation: A Social Cognitive Perspective. In M. Boekaerts, P. R. Pintrich, \& M. Zeidner (Eds.), Handbook of self-regulation (pp. 1339) San Diego, Academic Press.

Zimmerman, B, J, 2008. Investigating Self-regulation and Motivation: Historical Background, Methodological Developments, and Future Prospects. American Educational Research Journal, 45:1, 166-183. 

be applied to their work. Under the terms of this license, no permission is required from the author(s) or publisher for members of the community to copy, distribute, transmit or adapt the article content, providing a proper, prominent and unambiguous attribution to the authors in a manner that makes clear that the materials are being reused under permission of a Creative Commons License. Views, opinions and conclusions expressed in this research article are views, opinions and conclusions of the author(s). Open Access Publishing Group and European Journal of Alternative Education Studies shall not be responsible or answerable for any loss, damage or liability caused in relation to/arising out of conflict of interests, copyright violations and inappropriate or inaccurate use of any kind content related or integrated on the research work. All the published works are meeting the Open Access Publishing requirements and can be freely accessed, shared, modified, distributed and used in educational, commercial and non-commercial purposes under a Creative Commons Attribution 4.0 International License (CC BY 4.0). 